Jurnal Health Sains: p-ISSN : 2723-4339 e-ISSN : 2548-1398

Vol. 2, No. 2, Februari 2021

\title{
TINGKAT PENGETAHUAN IBU MENYUSUI TERHADAP ASI EKSKLUSIF DI PUSKESMAS JEULINGKE BANDA ACEH
}

\section{Hayatun Nufus, Emirelda dan Suriatul Laila}

Universitas Abulyatama Aceh, Aceh Besar, Indonesia

Email: bluegumi7@gmail.com,dr.emirelda@yahoo.com dan suriatullaila@gmail.com

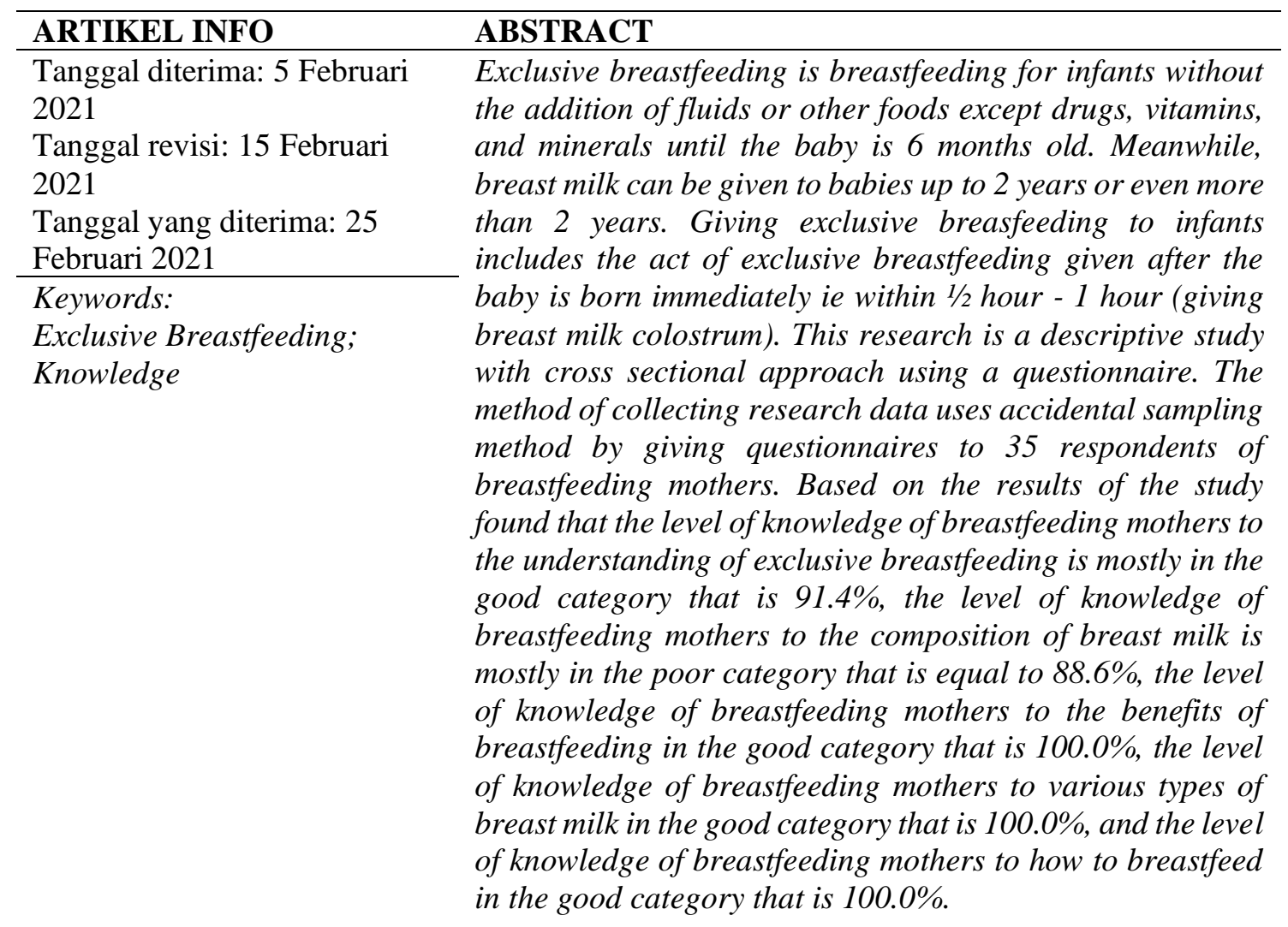

cccKata Kunci:

ASI Eksklusif; Pengetahuan

\begin{abstract}
ABSTRAK
ASI eksklusif ialah pemberian ASI kepada bayi tanpa disertai tambahan cairan ataupun makanan lain kecuali obat, vitamin, dan mineral sampai bayi berusia 6 bulan. Sementara itu, ASI dapat diberikan kepada bayi hingga berusia 2 tahun bahkan lebih dari 2 tahun. Pemberian ASI eksklusif pada bayi meliputi tindakan ASI eksklusif diberikan setelah bayi dilahirkan dengan segera yaitu dalam waktu $1 / 2$ jam -1 jam (memberikan kolostrum ASI). Penelitian ini merupakan penelitian deskriptif dengan pendekatan cross sectional dengan menggunakan kuisioner. Cara pengambilan data penelitian menggunakan metode accidental sampling dengan memberikan kuisioner pada 35 responden Ibu menyusui. Berdasarkan hasil penelitian didapatkan hasil bahwa tingkat pengetahuan Ibu menyusui terhadap pengertian ASI Eksklusif sebagian besar dalam kategori baik yaitu sebesar $91,4 \%$, tingkat pengetahuan Ibu menyusui terhadap
\end{abstract}




komposisi ASI sebagian besar dalam kategori kurang baik
yaitu sebesar $88,6 \%$, tingkat pengetahuan Ibu menyusui
terhadap manfaat ASI dalam kategori baik yaitu sebesar
$100,0 \%$, tingkat pengetahuan Ibu menyusui terhadap
beragam jenis ASI dalam kategori baik yaitu sebesar
$100,0 \%$, dan tingkat pengetahuan Ibu menyusui terhadap
cara pemberian ASI dalam kategori baik yaitu sebesar
$100,0 \%$.

Coresponden Author:

Email: bluegumi7@gmail.com

Artikel dengan akses terbuka dibawah lisensi

\section{Pendahuluan}

Air susu ibu (ASI) merupakan makanan yang pertama, utama dan terbaik pada awal usia kehidupan bayi yang bersifat alamiah. ASI ibarat emas yang diberikan gratis oleh Tuhan karena cairan yang kandungan zatnya dapat menyesuaikan kebutuhan gizi bayi (Noviana \& Purwati, 2011).

World Health Organitation (Organization, 2013) telah mengkaji atas lebih dari 3.000 penelitian menunjukkan pemberian ASI selama 6 bulan adalah jangka waktu yang paling optimal untuk pemberian ASI eksklusif. Hal ini didasarkan pada bukti ilmiah bahwa ASI eksklusif mencukupi kebutuhan gizi bayi lebih baik.

Maksud ASI eksklusif disini adalah pemberian ASI selama 6 bulan tanpa makanan tambahan lain seperti susu formula, buah, madu, teh, air putih, dan makanan padat lain seperti nasi, pisang, bubur dan tim sejak lahir hingga bayi berusia 6 bulan.

Kategori proses bayi mulai mendapat Air Susu ibu (ASI) adalah kurang dari 1 jam (inisiasi menyusu dini/IMD), antara 1 sampai 6 jam, 7 sampai 23 jam, 24 sampai 47 jam dan sama dengan atau lebih dari $47 \mathrm{jam}$. Dua puluh empat jam pertama setelah ibu melahirkan adalah saat yang sangat penting untuk keberhasilan menyusui selanjutnya (Rahayu et al., 2015). Pada jam-jam pertama setelah melahirkan dikeluarkan hormon 190 oksitosin yang bertanggung jawab terhadap produksi ASI. ASI mengandung kolostrum yang kaya akan antibodi karena mengandung protein untuk daya tahan tubuh dan pembunuh kuman dalam jumlah tinggi sehingga pemberian ASI eksklusif dapat mengurangi risiko kematian pada bayi (Roesli, 2000). Kolostrum berwarna kekuningan dihasilkan pada hari pertama sampai hari ketiga. Hari keempat sampai hari kesepuluh ASI mengandung immunoglobulin, protein dan laktosa lebih sedikit dibandingkan kolostrum tetapi lemak dan kalori lebih tinggi dengan warna susu lebih putih. Selain mengandung zat-zat makanan, ASI juga mengandung zat penyerap berupa enzim tersendiri yang tidak akan menganggu enzim di usus (Wulandari et al., 2020). Menyusui sejak dini mempunyai dampak yang positif bagi ibu maupun bayinya, bagi bayi kehangatan saat menyusu menurunkan risiko kematian karena hypothermia (kedinginan) (Kaban, 2017). Sedangkan manfaat bagi ibu adalah menyusui dapat mengurangi morbiditas dan mortalitas karena proses menyusui akan merangsang kontraksi uterus sehingga mengurangi perdarahan pasca melahirkan (postpartum).

Presentase anak berumur dibawah 6 bulan yang mendapat ASI Eksklusif meningkat dalam 5 tahun terakhir dari $42 \%$ pada SDKI 2012 menjadi 52\% pada SDKI 2017. Presentase anak yang tidak Jurnal Health Sains Vol. 2, No. 2, Februari 2021 
mendapatkan ASI naik dari $8 \%$ pada SDKI 2012 menjadi menjadi $12 \%$ pada SDKI 2017 (Kemenkes, 2018). Persentase pemberian ASI eksklusif pada bayi 0 - 6 bulan di Aceh pada tahun 2017 sebesar $55 \%$, peningkatan bila dibandingkan dengan tahun 2016 yang sebesar $50 \%$.

Pencapaian pemberian ASI Eksklusif di Banda Aceh belum mencapai target yang telah ditetapkan. Target pemberian ASI Eksklusif 6 bulan di Banda Aceh adalah sebesar $80 \%$ sedangkan pencapaiannya masih rendah yaitu 57,69\% dari tahun 2014-2018, dibawah target nasional yaitu $80 \%$.

Presentase data pemberian ASI Eksklusif di puskesmas Banda Aceh pada tahun 2019 di puskesmas Meuraxa sebesar $56,1 \%$, puskesmas Jaya Baru sebesar 69,7\%, puskesmas Banda Raya sebesar 34,4\%, puskesmas Baiturrahman sebesar 71\%, puskesmas Batoh sebesar 73,3 \%, puskesmas Kuta Alam sebesar 51,9\%, puskesmas Kuta Raja sebesar 39,9\%, puskesmas Jeulingke sebesar $66,6 \%$, dan puskesmas Ulee Kareng sebesar $73 \%$.

Pemberian ASI eksklusif harus dipraktikkan pada seluruh lapisan masyarakat untuk meningkatkan pengetahuan tentang pentingnya ASI eksklusif (Juliastuti, 2011). Rendahnya angka pencapaian ASI eksklusif kiranya perlu mendapatkan khusus karena berkontribusi terhadap rendahnya kualitas sumber daya manusia dimasa yang akan datang serta berdampak pula pada angka kesakitan serta kematian.

\section{Metode Penelitian}

Penelitian ini merupakan penelitian deskriptif dengan pendekatan cross sectional yaitu peneliti melihat tingkat pengetahuan ibu terhadap pemberian ASI eksklusif, melalui observasi atau pengukuran variabel pada satu saat tertentu. Penelitian akan dilaksanakan di Puskesmas Jeulingke, kota Banda Aceh.
Penelitian ini dilaksanakan Juli 2020 sejak tanggal 06 - 15, selama dua jam perhari dimulai dari pukul 09.00 wib hingga pukul 11.00 wib.

Sampel dalam penelitian ini adalah Ibu yang memiliki anak usia 0-3 tahun dan sedang melakukan kunjungan ke puskesmas Jeulingke, Banda Aceh. Teknik pengambilan sampel yang akan dilakukan ialah accidental sampling. Dimana pemilihan sampel dengan menetapkan subjek dan memenuhi kriteria penelitian, serta memenuhi kriteria inklusi.

1. Ibu yang memiliki anak berusia 0-3 tahun dan bersedia menjadi responden

2. Ibu yang memiliki anak berusia 0-3 tahun dan dalam keadaan sehat mental dan sadar

3. Ibu yang memiliki anak berusia 0-3 tahun dan mampu berkomunikasi dengan baik

4. Ibu yang memiliki anak berusia 0-3 tahun dan hadir saat penelitian dilakukan di puskesmas.

\section{Kriteria Eksklusi:}

1. Ibu yang memiliki anak berusia 0-3 tahun dan tidak bersedia menjadi responden

2. Ibu yang memiliki anak berusia 0-3 tahun dan dalam kondisi gangguan jiwa

3. Ibu yang memiliki anak berusia 0-3 tahun dan mengalami kecacatan (tulis,buta,bisu)

4. Ibu yang memiliki anak berusia 0-3 tahun dan tidak hadir saat pengambilan data.

Analisa data pada penelitian ini hanya dilakukan pada analisa univariat, sesuai dengan desain penelitian deskriptif yaitu untuk mengetahui bagaimana tingkat pengetahuan ibu menyusui terhadap ASI eksklusif dilakukan di variabel penelitian. Umumnya analisis ini hanya menghasilkan distribusi dan presentasi dari tiap variabel penelitian.

\section{Hasil Penelitian}

Tabel 1 
Karakteristik Ibu Menyusui Berdasarkan Umur

\begin{tabular}{ccc}
\multicolumn{3}{c}{ Umur } \\
\hline Umur & $\mathbf{N}$ & $\%$ \\
\hline $\begin{array}{l}\text { Masa Dewasa } \\
\text { Awal (26-35) }\end{array}$ & 35 & 100,0 \\
\hline
\end{tabular}

Pada tabel 1, dari 35 responden diketahui bahwa berdasarkan karakteristik umur seluruh responden berada di kategori masa dewasa awal yaitu 25-35 tahun sebanyak 35 orang $(100,0 \%)$.

\section{Tabel 2}

Karakteristik Ibu Menyusui Berdasarkan Pendidikan

\begin{tabular}{ccc}
\hline $\begin{array}{c}\text { Tingkat } \\
\text { pendidikan }\end{array}$ & $\mathbf{N}$ & $\%$ \\
\hline Tidak diketahui & 7 & 20,0 \\
\hline SMA & 9 & 25,7 \\
\hline D-3 & 5 & 14,3 \\
\hline S1 & 14 & 40,0 \\
\hline Total & 35 & 100,0 \\
\hline
\end{tabular}

Pada tabel 2, dari 35 responden diketahui bahwa tingkat pendidikan responden tidak diketahui sebanyak 7 orang $(20,0 \%)$, tingkat pendidikan SMA sebanyak 9 orang $(25,7 \%)$, tingkat pendidikan D-3 sebanyak 5 orang $(14,3 \%)$, dan tingkat pendidikan S-1 sebanyak 14 orang $(40,0 \%)$.

Tabel 3

Karakteristik Ibu Menyusui Berdasarkan Pekerjaan

\begin{tabular}{ccc}
\hline Pekerjaan & N & \% \\
\hline IRT & 20 & 57,1 \\
\hline Swasta & 10 & 28,6 \\
\hline PNS & 5 & 14,3 \\
\hline Total & 35 & 100,0 \\
\hline
\end{tabular}

Pada tabel 3, dari 35 responden diketahui bahwa responden dengan pekerjaan sebagai IRT sebanyak 20 orang $(57,1 \%)$, responden dengan pekerjaan di bidang swasta sebanyak 10 orang $(28,6 \%)$, dan responden dengan pekerjaan PNS sebanyak 5 orang $(14,3 \%)$.
Tabel 4

Tingkat Pengetahuan Ibu Menyusui Terhadap Pengertian ASI Eksklusif

\begin{tabular}{ccc}
\hline Pengetahuan & $\mathbf{N}$ & $\mathbf{\%}$ \\
\hline Kurang & 3 & 8,6 \\
\hline Baik & 32 & 91,4 \\
\hline Total & 35 & 100,0 \\
\hline
\end{tabular}

Pada tabel 4, dari 35 responden diketahui bahwa pengetahuan responden terhadap penelitian ini menunjukkan bahwa tingkat pengetahuan ibu menyusui terhadap pengertian ASI Eksklusif dengan pengetahuan kurang baik sebanyak 3 orang $(8,6 \%)$ dan pengetahuan baik sebanyak 32 orang $(91,4 \%)$.

Tabel 5

Tingkat Pengetahuan Ibu Menyusui Terhadap Komposisi ASI Eksklusif

\begin{tabular}{ccc}
\hline $\begin{array}{c}\text { Komposisi } \\
\text { ASI }\end{array}$ & $\mathbf{N}$ & $\boldsymbol{\%}$ \\
\hline Kurang & 31 & 88,6 \\
\hline Baik & 4 & 11,4 \\
\hline Total & 35 & 100,0 \\
\hline
\end{tabular}

Tabel 6

Tingkat Pengetahuan Ibu Menyusui Terhadap Manfaat Pemberian ASI Eksklusif

\begin{tabular}{ccc}
\hline $\begin{array}{c}\text { Manfaat } \\
\text { pemberian } \\
\text { ASI Eksklusif }\end{array}$ & $\mathbf{N}$ & $\boldsymbol{\%}$ \\
\hline kurang & 0 & 0,0 \\
\hline baik & 35 & 100,0 \\
\hline Total & 35 & 100,0 \\
\hline
\end{tabular}

Pada tabel 6, dari 35 responden diketahui bahwa tingkat pengetahuan terhadap manfaat pemberian ASI Eksklusif dengan pengetahuan kurang baik sebanyak 0 orang $(0,0 \%)$ dan responden dengan tingkat pengetahuan baik sebanyak 35 orang $(100,0 \%)$.

Tabel 7

Tingkat Pengetahuan Ibu Menyusui Terhadap Beragam Jenis ASI

\begin{tabular}{ccc}
\hline Jenis ASI & $\mathbf{N}$ & $\mathbf{\%}$ \\
\hline Kurang & 0 & 0,0 \\
\hline Baik & 35 & 100,0 \\
\hline Total & 35 & 100,0 \\
\hline
\end{tabular}


Pada tabel 7, dari 35 responden diketahui bahwa tingkat pengetahuan terhadap beragam jenis ASI dengan pengetahuan kurang baik sebanyak 0 orang $(0,0 \%)$ dan responden dengan tingkat pengetahuan baik sebanyak 35 orang $(100,0 \%)$.

Tabel 8

\begin{tabular}{|c|c|c|}
\hline \multicolumn{3}{|c|}{$\begin{array}{l}\text { Tingkat Pengetahuan Ibu Menyus } \\
\text { Terhadap Cara Pemberian ASI }\end{array}$} \\
\hline $\begin{array}{c}\text { Cara Pemberian } \\
\text { ASI }\end{array}$ & $\mathbf{N}$ & $\%$ \\
\hline Kurang & 0 & 0,0 \\
\hline Baik & 35 & 100,0 \\
\hline Total & 35 & 100,0 \\
\hline
\end{tabular}

Pada tabel 8, dari 35 responden diketahui bahwa tingkat pengetahuan terhadap cara pemberian ASI dengan pengetahuan kurang baik sebanyak 0 orang $(0,0 \%)$ dan dengan pengetahuan baik sebanyak 35 orang $(100,0 \%)$

\section{Pembahasan}

ASI eksklusif adalah pemberian ASI selama 6 bulan tanpa makanan tambahan lain seperti susu formula, buah, madu, teh, air putih, dan makanan padat lain seperti nasi, pisang, bubur dan tim sejak lahir hingga bayi berusia 6 bulan (Wirawan et al., 2018). Dari hasil penelitian diketahui bahwa tingkat pengetahuan ibu menyusui terhadap ASI Eksklusif di Puskesmas Jeulingke pada tabel 4 mempunyai kategori baik yaitu sebanyak 32 responden $(91,4 \%)$ dan kategori kurang baik sebanyak 3 responden $(8,6 \%)$. Ini dikarenakan faktor usia responden yang sebagian besar berada pada masa dewasa awal ( $25-35$ tahun) seperti yang terdapat pada tabel 1 . Umur ibu sangat menentukan kesehatan maternal dan berkaitan dengan kondisi kehamilan, peralinan dan nifas serta cara mengasuh dan menyusui bayinya (Saraung et al., 2017). Ibu yang berumur kurang dari 20 tahun dianggap masih belum matang dan belum siap dalam hal jasmani dan social dalam menghadapi kehamilan, persalinan serta membina bayi yang baru dilahirkan. Sedangkan ibu yang berusia 25 - 35 tahun disebut sebagai masa dewasa awal dan disebut juga masa reproduksi, dimana pada masa ini diharapkan ibu telah mampu untuk memecahkan masalah yang dihapadi dengan tenang secara emosional, terutama menghadapi kehamilan, persalinan, nifas, dan merawat bayinya nanti. Berdasarkan hasil penelitian (Susanti \& Sari, 2020), dengan judul Tingkat Pengetahuan Ibu Menyusui Yang Mempunyai Anak Pertama Usia 0-6 bulan Tentang ASI Eksklusif diketahui bahwa tingkat pengetahuan berdasarkan faktor usia mempunyai kategori sedang yaitu sebesar 30 responden $(41,10 \%)$.

a. Tingkat pengetahuan Ibu Menyusui terhadap Komposisi ASI Eksklusif

Berdasarkan tabel 5, dari 35 responden diketahui bahwa tingkat pengetahuan responden terhadap komposisi ASI Eksklusif dengan pengetahuan kurang baik sebanyak 31 orang $(88,6 \%)$ dan responden dengan pengetahuan baik sebanyak 4 orang $(11,4 \%)$.

Komposisi ASI yaitu kolostrum yaitu ASI yang keluar dari hari pertama sampai hari ke 4 setelah melahirkan, Lebih banyak mengandung protein dibanding dengan ASI yang matur, tetapi berlainan dengan ASI yang matur (Siregar, 2004). Pada kolostrum protein yang utama adalah globulin (gamma globulin). ASI juga mengandung nutriennutrien khusus yang diperlukan otak bayi agar tumbuh optimal, antara lain lemak, karbohidrat, protein, garam, mineral dan vitamin.

Dari penelitian Meri Oktaria menyimpulkan bahwa tingkat pengetahuan Ibu menyusui terhadap ASI Eksklusif sudah cukup baik, akan tetapi dalam hal mengenai kolostrum hanya 
sedikit yang pernah mendengar $(23,3 \%)$ dan tahu (22,1\%) (Habiba, 2016).

b. Tingkat pengetahuan Ibu Menyusui terhadap Manfaat Pemberian ASI Eksklusif

Berdasarkan tabel 6 , dari 35 responden diketahui bahwa tingkat pengetahuan terhadap manfaat pemberian ASI Eksklusif dengan pengetahuan kurang baik sebanyak 0 orang $(0,0 \%)$ dan responden dengan tingkat pengetahuan baik sebanyak 35 orang $(100,0 \%)$.

Manfaat pemberian ASI yaitu membuat bayi jauh lebih sehat, meningkatkan kekebalan, kecerdasan emosional dan spiritual lebih baik dibandingkan dengan anak-anak yang ketika bayi tidak diberi ASI ekslusif . ASI dapat mengurangi angka kematian bayi karena meningkatkan daya imunitasnya sehingga lebih tahan terhadap penyakit.Selain itu, ASI mengandung zat gizi yang selalu disesuaikan dengan kebutuhan bayi.

Dari penelitian Lelia Kusuma Astuti didapatkan pengatahuan ibu menyusui tentang ASI eksklusif sebagian besar responden (79\%) memahami pengertian ASI eksklusif dan $75 \%$ responden memahami manfaat ASI eksklusif (Astuti, 2009). Hasil penelitian ini menunjukkan angka yang lebih baik dibandingkan hasil dari penelitian terhadap 900 ibu disekitar Jabotabek pada tahun 1995 yang diperoleh fakta bahwa 70,4\% ibu tidak pernah mendengar informasi tentang ASI eksklusif. Tetapi hasil penelitian juga menunjukkan bahwa sebanyak $25 \%$ responden belum memahami pengertian kolustrum, dan masih ada $10 \%$ responden yang berpendapat bahwa kolustrum tidak dapat diberikan kepada bayi.

c. Tingkat pengetahuan Ibu menyusui terhadap beragam jenis ASI
Berdasarkan tabel 7 , dari 35 responden diketahui bahwa tingkat pengetahuan terhadap beragam jenis ASI dengan pengetahuan kurang baik sebanyak 0 orang $(0,0 \%)$ dan responden dengan tingkat pengetahuan baik sebanyak 35 orang $(100,0 \%)$.

Dari penelitian Syera Wahyuni diketahui bahwa dari 40 responden yang memiliki tingkat pengetahuan yang baik tentang beragam jenis ASI eksklusif sebanyak 27 orang $(67,50 \%)$ dengan rincian umur responden di atas 36 tahun sebanyak 1 orang $(2,50 \%)$, umur $21-35$ tahun sebanyak 26 orang (65\%). Responden yang memiliki tingkat pengetahuan tentang ASI Eksklusif cukup sebanyak 8 orang $(20 \%)$ yang kesemuanya berasal dari kelompok umur antara $21-35$ tahun, sedangkan responden yang memiliki tingkat pengetahuan tentang ASI eksklusif yang kurang sebanyak 5 orang $(12,50 \%)$ yang bersal dari kelompok umur antara $21-35$ tahun sebanyak 4 orang $(10 \%)$ dan kelompok umur lebih kecil dari 20 tahun sebanyak 1 orang $(2,50 \%)$. Hasil uraian tersebut menunjukkan bahwa manyoritas responden berada pada tingkat umur sedang yaitu 21 - 35 tahun dan rata-rata memiliki tingkat pengetahuan yang baik (65\%) tentang ASI Eksklusif.

d. Tingkat pengetahuan Ibu menyusui terhadap cara pemberian ASI

Berdasarkan tabel 8, dari 35 responden diketahui bahwa tingkat pengetahuan terhadap cara pemberian ASI dengan pengetahuan kurang baik sebanyak 0 orang $(0,0 \%)$ dan dengan pengetahuan baik sebanyak 35 orang $(100,0 \%)$.

Dari penelitian Nordahayu Binti Jalal responden yang mempunyai pengetahuan baik dan memberikan ASI eksklusif pada bayi sebanyak 32 orang 
$(69,6 \%)$ dan responden dengan pengetahuan baik tetapi tidak memberikan ASI eksklusif pada bayi sebanyak 9 orang $(19,6 \%)$. Sedangkan responden dengan pengetahuan sedang dan pengetahuan kurang baik masingmasing tidak memberikan ASI eksklusif yaitu sebanyak 4 orang $(8,7 \%)$ untuk pengetahuan sedang dan 1 orang $(2,2 \%)$ untuk pengetahuan kurang baik.

\section{Kesimpulan}

Berdasarkan hasil penelitian yang telah diuraikan di bab sebelumnya, maka dapat ditarik beberapa kesimpulan pertama tingkat pengetahuan Ibu menyusui terhadap pengertian ASI Eksklusif sebagian besar dalam kategori baik yaitu sebesar 91,4\%, kedua tingkat pengetahuan Ibu menyusui terhadap komposisi ASI sebagian besar dalam kategori kurang baik yaitu sebesar $88,6 \%$, ketiga tingkat pengetahuan Ibu menyusui terhadap manfaat ASI dalam kategori baik yaitu sebesar 100,0\%, keempat tingkat pengetahuan Ibu menyusui terhadap beragam jenis ASI dalam kategori baik yaitu sebesar $100,0 \%$, kelima tingkat pengetahuan Ibu menyusui terhadap cara pemberian ASI dalam kategori baik yaitu sebesar 100,0\% .

\section{BIBLIOGRAFI}

Astuti, L. K. (2009). Studi Deskriptif Tingkat Pengetahuan Ibu Menyusui Tentang Asi Eksklusif Di Puskesmas Cilacap Utara. Kes Mas: Jurnal Fakultas Kesehatan Masyarakat Universitas Ahmad Daulan, 3(3), 24830.

Habiba, S. (2016). Faktor-Faktor Yang Mempengaruhi Pemberian Asi Eksklusif Di Wilayah Kerja Puskesmas Kebakkramat Ii Kabupaten Karanganyar Tahun 2016. Universitas Negeri Semarang.

Jurnal Health Sains Vol. 2, No. 2, Februari 2021
Juliastuti, R. (2011). Hubungan Tingkat Pengetahuan, Status Pekerjaan Ibu, Dan Pelaksanaan Inisiasi Menyusu Dini Dengan Pemberian Asi Eksklusif. Uns (Sebelas Maret University).

Kaban, N. B. (2017). Inisiasi Menyusui Dini. Jurnal Keluarga Sehat Sejahtera, 15(2), 35-46.

Kemenkes, R. I. (2018). Hasil Utama Riset Kesehatan Dasar Tahun 2018. Kementrian Kesehatan Republik Indonesia, 1-100.

Noviana, N., \& Purwati, Y. (2011). Hubungan Pelaksanaan Inisiasi Menyusu Dini Dengan Pemberian Asi Ekslusif Oleh Ibu Yang Mempunyai Bayi Usia 6-12 Bulan Di Desa Wijimulyo Nanggulan Kulon Progo Yogyakarta. Stikes'aisyiyah Yogyakarta.

Organization, W. H. (2013). Global Tuberculosis Report 2013. World Health Organization.

Rahayu, D., Santoso, B., \& Yunitasari, E. (2015). Produksi Asi Ibu Dengan Intervensi Acupresure Point Lactation Dan Pijet Oksitosin (The Difference In Breastmilk Production Between Acupresure Point For Lactation And Oxytocin Massage). Jurnal Ners, 10(1).

Roesli, U. (2000). Mengenal Asi Eksklusif. Niaga Swadaya.

Saraung, M. W., Rompas, S., \& Bataha, Y. B. (2017). Analisis Faktor-Faktor Yang Berhubungan Dengan Produksi Asi Pada Ibu Postpartum Di Puskesmas Ranotana Weru. Jurnal Keperawatan, 5(2).

Siregar, A. (2004). Pemberian Asi Eksklusif Dan Faktor-Faktor Yang Mempengaruhinya. In Medan: Fkm Usu.

Susanti, E. T., \& Sari, H. L. (2020). Pendidikan Kesehatan Tentang JenisJenis Alat Kontrasepsi Terhadap 
Hayatun Nufus, Emirelda dan Suriatul Laila

Pemilihan Alat Kontrasepsi. Jurnal Kesehatan, 9(1), 53-57.

Wirawan, N. N., Purwestri, R. C., Fahmi, I., Jati, I. R. A. P., Kariuki, L. W., Barati, Z., Hartung, J., Lusiana, B., \& Biesalski, H. K. (2018). Food Consumption And Dietary Diversity Of Women In Transmigrant Area Buol, Central Sulawesi And Original Location Demak, Central Java, Indonesia. Malaysian Journal Of Nutrition, 24(4), 587-596.

Wulandari, A. T., Mayangsari, D., Nihayah, A., \& Afriani, A. I. (2020). Persepsi Ibu Yang Bekerja Terhadap Kegagalan Pemberian Asi Eksklusif Pada Bayi Di Wilayah Sambiroto Semarang 2017. 